\title{
Membangun Supply Chain Resilience dengan Pendekatan Quality Function Development: Studi Kasus Perusahaan Freight Forwarder
}

\author{
Saraswati A., Baihaqi I., dan Anggrahini D. \\ Departemen Manajemen Bisnis, Fakultas Bisnis dan Manajemen Teknologi Institut Teknologi Sepuluh Nopemner
}

(ITS)

\begin{abstract}
Abstrak-Supply chain resilience diperlukan untuk perusahaan supaya dapat menurunkan dampak dari risiko-risiko yang dapat terjadi pada perusahaan. Tujuan dari penelitian ini yaitu untuk menganalisis supply chain resilience pada Perusahaan Freight Forwarder yang merupakan salah satu pemain dalam industri logistik maritim. Penelitian ini mengadopsi pendekatan Quality Function Deployment (QFD) yang mempertimbangkan kebutuhan pelanggan dan risiko maritim. Hasil dari penelitian ini yaitu terdapat tiga prioritas kebutuhan pelanggan yaitu pengiriman yang mudah dan tepat waktu, pelayanan yang cepat dan pengiriman yang aman. Lalu didapatkan tiga prioritas risiko yaitu kerusakan alat komunikasi, kesalahan dalam pelayanan, dan kesalahan dalam penanganan dokumen. Lalu tiga prioritas penyebab risiko yaitu kurangnya keterampilan karyawan, gangguan pada server INSW, dan kurangnya motivasi karyawan. Lalu tiga prioritas yaitu memberikan pelatihan mengenai cara berkomunikasi yang baik, menggunakan sistem penilaian kinerja karyawan dengan Key Performance Indicators (KPI) setiap bulan, dan memberikan pelatihan mengenai ekspor dan impor kepada karyawan.
\end{abstract}

Kata Kunci-logistik maritim, QFD, risiko supply chain, supply chain resilience.

\section{PENDAHULUAN}

$\mathrm{T}$ IGA pemain kunci membentuk sistem maritim logistik yaitu shipping line, operator pelabuhan/terminal dan freight forwarder [1]. Freight forwarder merupakan usaha yang menangani dokumen, pengiriman barang untuk dieskpor, penerimaan barang impor dan bea cukai. Perusahaan yang menjadi objek pada penelitian ini yaitu Perusahaan Freight Forwarder yang merupakan perusahaan yang bergerak di bidang freight forwarder. Terjadi peningkatan kebutuhan pelanggan contohnya seperti perusahaan manufaktur mencari paket logistik yang terintegrasi yang dapat memberikan nilai tambah untuk kargo mereka melalui perjalan rantai pasok, daripada melalui layanan transportasi terfragmentasi tradisional[1]. Selain itu, menurut [2], pelanggan berharap penyedia layanan logistik untuk memberikan layanan berkualitas seperti pengiriman tepat waktu, jaringan luas dan fleksibel. Salah satu pelanggan dari Perusahaan Freight Forwarder mengatakan bahwa Perusahaan Freight Forwarder diharapkan dapat menyebarkan informasi terkini mengenai peraturan dan kondisi seputar layanan kepada mereka dan pihak Perusahaan Freight Forwarder mudah untuk dihubungi. Hal ini diharapkan supaya pelanggan tidak salah langkah sehingga proses impor dan ekspor berjalan lancar. Selain itu, pelanggan juga membutuhkan peran dari freight forwarder dalam menyelesaikan berbagai macam masalah seputar kegiatan impor ekspor. Salah satunya yaitu Perusahaan Freight Forwarder diharapakan dapat mengeluarkan barang milik pelanggan yang memiliki berat berlebih atau overweight.

Selain kebutuhan pelanggan yang semakin meningkat tersebut, perusahaan juga harus memperhatikan risiko-risiko yang dapat terjadi pada perusahaan. Risiko juga terdapat pada perusahaan logistik maritim. Risiko maritim terdiri dari banyak tipe sesuai dengan tugas dari perusahaan itu sendiri [3]. Adanya risiko ini dapat berpengaruh secara tidak langsung pada kepuasan pelanggan. Selain itu, risiko juga dapat berpengaruh pada rantai pasok. Hal ini terjadi karena rantai pasok dibentuk oleh beberapa perusahaan yang bertindak sebagai bagian dari sistem logistik yang panjang dan rumit. Sehingga jika risiko terjadi maka akan berpengaruh kepada pihak lainnya di dalam rantai pasok tersebut. Maka dari itu, risiko dalam rantai pasok ini menjadi fokus yang menarik dalam bidang logistic [4]. Dalam menilai kerentanan rantai pasokan perusahaan perylu mengidentifikasi risiko tidak hanya untuk operasi mereka sendiri tetapi juga untuk semua entitas lainnya. Sebuah gangguan yang mempengaruhi entitas di mana saja dalam rantai pasokan dapat memiliki efek langsung pada kemampuan perusahaan untuk melanjutkan operasi.

Setelah rantai pasok terkena gangguan, maka kinerja rantai pasok akan terancam, dalam hal profitabilitas antara lain struktur biaya dan persediaan [5]. Selain itu, gangguan rantai pasok juga mempengaruhi tingkat kepuasan keseluruhan perusahaan mulai dari hilir hingga end-customers [6]. Risiko yang terdapat pada Perusahaan Freight Forwarder antara lain yaitu adanya bencana alam seperti puting beliung, angin topan, tsunami, banjir dan tanah longsor yang dapat menghalangi proses ekspor impor. Selain itu, risiko adanya pemogokan buruh di pelabuhan dapat menghambat proses ekspor impor karena di pelabuhan tidak ada kegiatan.

Untuk dapat bertahan, rantai pasok harus reliable atau dapat diandalkan. Supply chain resilience adalah kemampuan rantai pasok untuk kembali ke kondisi semula atau ke keadaan yang lebih diinginkan setelah terkena gangguan dan untuk menghindari terjadinya kegagalan [7].

Mengingat pentingnya ketahanan rantai pasok tersebut, maka penelitian ini mengadopsi pendekatan Quality Function Deployment untuk memprioritaskan langkah-langkah ketahanan untuk perusahaan dari perspektif rantai pasok dengan mempertimbangkan kebutuhan konsumen dan risiko 
maritim. Pada penelitian ini menggunakan alat yaitu House of Quality (HOQ).

\section{LANDASAN TEORI}

Pada penelitian ini menggunakan pendekatan QFD untuk memprioritaskan langkah-langkah ketahanan untuk perusahaan dari perspektif rantai pasok dengan mempertimbangkan kebutuhan konsumen dan risiko. Fase yang pertama dalam QFD yaitu perencanaan produk dapat disebut juga sebagai HOQ. Berikut merupakan langkahlangkah dalam pembuatan HOQ menurut penelitian [8].

1. Identifikasi dan Memprioritaskan Customer Requirements (CR). Melakukan studi literatur mengenai kebutuhan pelanggan yang ada di logistik maritim dan melakukan wawancara dengan direktur dan manajer mengenai kebutuhan pelanggan. Penilaian (Importance Weight) dilakukan melalui wawancara dengan pelanggan. Menggunakan skala Likert dari skor 1 hingga 5. Selanjutnya menghitung pembobotan atau Weight (W).

$$
W_{i}=\frac{I_{i}}{\sum_{i=1}^{n} I_{i}}, \quad i=1, n
$$

2. Identifikasi dan penilaian Design Requirements (DR) Melakukan studi literatur mengenai risiko yang ada di logistik maritim. Melakukan wawancara dengan direktur dan manajer dan penilaian likelihood, impact dan effectiveness untuk potensi risiko dengan menggunakan skala Likert dari skor 1 hingga 5.

3. Penilaian Relationship Matrix - Hubungan yang dinilai yaitu dampak yang dapat ditimbulkan oleh potensi risiko terhadap kebutuhan pelanggan. Hubungan ini ditunjukan dengan menggunakan dengan skor 1, 3 dan 9. Yang mana tingkat korelasinya rendah, sedang dan kuat. Relationship Matrix menggunakan penilaian yang sudah dirata-rata.

4. Penilaian Technical Matrix - Menghitung Absolute Importance (AI) dan Relative Importance (RI). Hasil dari penilaian diberi peringkat dari yang terbesar hingga yang terkecil.

$$
\begin{array}{lr}
A I=\sum_{i=1}^{n} W_{i} R_{i j}, & j=1, \ldots m . \\
R I=\frac{A I_{j}}{\sum_{j=1}^{m} A I_{j}}, & j=1, \ldots m .
\end{array}
$$

\section{METODOLOGI PENELITIAN}

Jenis data yang digunakan dalam penelitian ini adalah data primer yakni hasil wawancara dengan pihak perusahaan serta pelanggan. Selain itu juga menggunakan data sekunder berupa hasil studi literatur. Metode wawancara dilakukan melalui indepth interview. Sedangkan untuk pengambilan data data yang membutuhkan pengukuran atau penilaian dilakukan dengan menggunakan wawancara terstruktur.

Metode QFD yang digunakan dalam penelitian ini mengacu pada metode yang digunakan pada [8]. Narasumber pada penelitian ini dari pihak perusahaan yaitu direktur dan manajer ekspor impor. Selain itu terdapat narasumber dari pihak pelanggan pula. Wawancara dilakukan dari bulan Desember 2016 hingga Maret 2017. Pada penelitian ini dilakukan pembuatan 3 HOQ. Pada HOQ 1 berisi mengenai hubungan antara kebutuhan pelanggan dengan potensi risiko. Tujuan dari HOQ 1 ini yaitu mengidentifikasi keterkaitan risiko maritim yang dapat mempengaruhi daya saing perusahaan menurut kebutuhan pelanggan. Pada HOQ 2 merupakan lanjutan dari HOQ 1. HOQ 2 ini berisi mengenai hubungan antara risiko dengan penyebab risiko. Lalu pada HOQ 3 berisi mengenai hubungan antara penyebab risiko dengan resilience measures yang diharapkan dapat memitigasi risiko yang sudah diidentifikasi. Tahapan dapat dilihat pada Gambar 1.
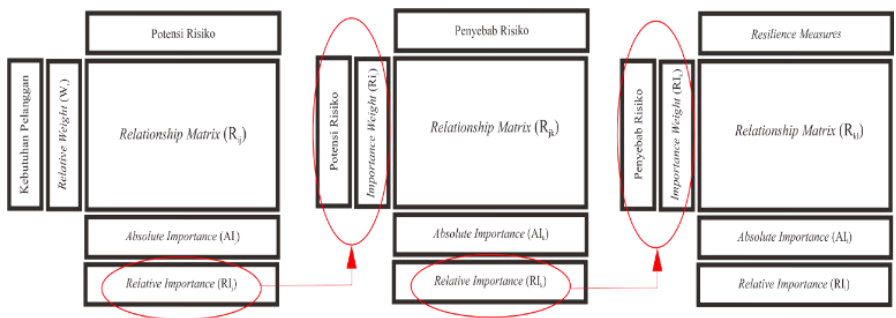

Gambar 1.Tahapan penelitian menggunakan HOQ.

\section{STUDI KASUS}

Studi kasus dilakukan di Perusahaan Freight Forwarder yang merupakan perusahaan yang bergerak di industri logistik maritim yaitu freight forwarder. perusahaan ini menyediakan layanan untuk keperluan ekspor dan impor.

\section{ANALISIS DAN PEMBAHASAN}

Hal yang pertama dilakukan yaitu melakukan identifikasi dan penilaian untuk kebutuhan pelanggan. Berikut merupakan hasil identifikasi dan penilaian kebutuhan pelanggan yang ditunjukkan pada Tabel 1.

Tabel 1.

Hasil Identifikasi dan Penilaian Kebutuhan Pelanggan

\begin{tabular}{ccc}
\hline \hline No. & Kebutuhan Pelanggan & $\begin{array}{c}\text { Importance } \\
\text { Weight (Ii) }\end{array}$ \\
\hline 1 & Pengiriman yang mudah dan tepat waktu & 5 \\
2 & Pelacakan pengiriman barang yang mudah & 5 \\
dan real-time & 4 \\
4 & Layanan pelanggan yang profesional & 5 \\
5 & Pelayanan yang cepat & 5 \\
6 & Pengiriman aman & 5 \\
7 & Tidak ada kesalahan pada invoice dan B/L & 5 \\
8 & Pelayanan warehousing aman & 5 \\
9 & Information sharing & 4 \\
10 & Dapat menangani masalah pengeluaran & 4 \\
11 & barang overweight & 5 \\
12 & Dapat menangani masalah pengangkutan & 5 \\
13 & barang overweight & 5 \\
14 & Dapat menangani masalah ketidaksesuaian & 5 \\
15 & dokumen & 5 \\
16 & Tidak ada keterlambatan pengiriman & 5 \\
\hline \hline
\end{tabular}

Berikut merupakan hasil dari perhitungan HOQ 1 yang ditunjukkan pada Tabel 2. Selain itu, hasil HOQ 1 yaitu 
terdapat 5 peringkat tertinggi yang meliputi kerusakan alat komunikasi, kesalahan dalam pelayanan, kesalahan dalam penanganan dokumen, keterlambatan penangan dokumen oleh Bea dan Cukai, dan ketidaksesuaian dokumen. Dari hasil tersebut terdapat perbedaan dengan hasil dari penelitian [8] yang mengemukakan bahwa risiko sistem IT menempati peringkat yang pertama. Sedangkan pada penelitian ini menunjukan hasil bahwa potensi risiko peringkat pertama yaitu kerusakan alat komunikasi. Selain itu peringkat risiko yang kedua yaitu kesalahan dalam pelayanan berbeda dengan penelitian[8] yang menyatakan risiko operasional. Posisi risiko sumber daya manusia pada penelitian ini menempati peringkat kedua dan ketiga, kemudian dilanjutkan dengan risiko operasional.

Tabel 2.

Hasil Peringkat Potensi Risiko

\begin{tabular}{cc}
\hline \hline Peringkat & Potensi Risiko \\
\hline 1 & Kerusakan alat komunikasi \\
2 & Kesalahan dalam pelayanan \\
3 & Kesalahan dalam penanganan dokumen \\
4 & Keterlambatan penanganan dokumen oleh Bea dan \\
5 & Ketidaksesuaian dokumen \\
6 & Bencana alam \\
7 & Keterlambatan penanganan dokumen oleh shipping line \\
8 & Kemacetan dan peraturan buka-tutup jalan \\
9 & Kerusakan dan kecelakaan trucking \\
10 & Sistem IT down \\
11 & Pemogokan buruh di pelabuhan \\
12 & Tidak tersedianya trucking \\
13 & Kerusakan crane kapal \\
14 & Kerusakan crane darat \\
15 & Pencurian di warehouse \\
16 & Kepadatan di pelabuhan \\
17 & Ketidaksesuaian jadwal kapal dengan pelanggan \\
\hline \hline
\end{tabular}

Setelah melakukan pembuatan HOQ 1, maka dilanjutkan dengan pembuatan HOQ 2. Berikut merupakan hasil dari perhitungan HOQ 2 yang ditunjukkan pada Tabel 3. Penyebab risiko yang mendapatkan peringkat paling tinggi yaitu kurangnya keterampilan karyawan. Hal ini dikarenakan penyebab risiko ini memiliki hubungan atau memiliki dampak yang cukup besar terhadap terjadinya risiko-risiko yang telah diidentifikasi sebelumnya. Kurangnya keterampilan karyawan ini dapat berupa kurangnya ketelitian, kurangnya ketanggapan, kurangnya kecepatan, kurangnya kemampuan dalam berkomunikasi dan sebagainya.

Penyebab risiko yang mendapatkan peringkat kedua yaitu gangguan pada server INSW. Penyebab risiko yang menduduki peringkat kedua yaitu gangguan pada server INSW. INSW merupakan portal web yang menjadi pintu utama dalam proses ekspor dan impor. Dengan adanya gangguan terhadap server INSW tentu dapat menghambat proses pengiriman maupun penerimaan dokumen dengan pihak Bea dan Cukai.

Sedangkan penyebab risiko yang mendapatkan peringkat ketiga yaitu kurangnya motivasi karyawan. Banyak dari literatur menyebutkan bahwa ada hubungan antara motivasi karyawan dengan kinerja karyawan. Semakin tinggi motivasi karyawan maka akan berpengaruh terhadap meningkatnya kinerja karyawan.

Tabel 3

Hasil Peringkat Penyebab Risiko

\begin{tabular}{cc}
\hline \hline Peringkat & Penyebab Risiko \\
\hline 1 & Kurangnya keterampilan karyawan \\
2 & Gangguan pada server INSW \\
3 & Kurangnya motivasi karyawan \\
4 & Serangan hacker \\
5 & Proses penanganan dokumen oleh karyawan Bea dan \\
6 & Cukai yang kurang cepat \\
7 & Ketidakhadiran pejabat yang bersangkutan \\
8 & Proses penanganan dokumen oleh karyawan dari \\
9 & shipping line yang kurang cepat \\
10 & Cuaca buruk \\
11 & Adanya aturan mengenai larangan beroperasi untuk \\
12 & angkutan barang \\
13 & Adanya kerusakan jalan, kecelakaan, jembatan putus \\
& dan padatnya kendaraan di area tertentu. \\
14 & Permintaan pasar trucking yang meningkat \\
15 & Kesalahan dalam pengisian data maupun pengecekan \\
16 & dokumen oleh pelanggan \\
17 & Kalam pengisian data oleh pihak supplier \\
18 & Padatnya antrian untuk kapal curah \\
19 & Kurangnya pemeliharaan pada trucking \\
20 & Kistem keamanan warehouse yang kurang maksimal \\
21 & Kurangnya keterampilan karyawan warehouse \\
22 & Kerusakan pada mesin trucking \\
23 & Perubahan peraturan yang membebani buruh pelabuhan \\
24 & Kurangnya keterampilan karyawan vendor crane \\
\hline & \\
&
\end{tabular}

Setelah melakukan pembuatan HOQ 2, maka dilanjutkan dengan pembuatan HOQ 3. Berikut merupakan hasil dari perhitungan HOQ 3 yang ditunjukkan pada Tabel 4. Resilience measures yang menduduki pertingkat pertama yaitu memberikan pelatihan mengenai cara berkomunikasi yang baik.. Lalu untuk peringkat kedua yaitu menggunakan sistem penilaian kinerja dengan KPI yang dilakukan setiap bulan. Lalu dilanjutkan dengan peringkat ketiga yaitu memberikan pelatihan mengenai ekspor dan impor kepada karyawan. Hasil penelitian ini mempunyai sedikit perbedaan peringkat dengan hasil penelitian [8]. Perbedaan yang pertama yaitu penelitian [8] yang menyatakan bahwa resilience measures peringkat pertama yaitu rencana kontingensi. Lalu peringkat kedua yaitu monitoring dan pemeliharaan. Namun pada penelitian ini monitoring dan pemeliharaan terdapat pada peringkat kelima dan juga pada peringkat keenam. Untuk peringkat resilience measures selanjutnya, penelitian [8] menyatakan bahwa supply chain relationship management yang menduduki peringkat ketiga. Sedangkan pada penelitian ini mendapatkan hasil bahwa supply chain relationship management menempati peringkat keempat. 
Tabel 4.

Hasil Peringkat Resilience Measures

\begin{tabular}{|c|c|}
\hline Peringkat & Resilience Measures \\
\hline 1 & $\begin{array}{l}\text { Memberikan pelatihan mengenai cara berkomunikasi yang } \\
\text { baik. }\end{array}$ \\
\hline 2 & $\begin{array}{c}\text { Menggunakan sistem penilaian kinerja dengan KPI yang } \\
\text { dilakukan setiap bulan. }\end{array}$ \\
\hline 3 & $\begin{array}{c}\text { Memberikan pelatihan mengenai ekspor dan impor kepada } \\
\text { karyawan. }\end{array}$ \\
\hline 4 & Menjalin komunikasi yang baik dengan pelanggan. \\
\hline 5 & $\begin{array}{c}\text { Melakukan pengontrolan dan menjalin komunikasi yang } \\
\text { baik dengan pihak Bea dan Cukai. }\end{array}$ \\
\hline 6 & $\begin{array}{c}\text { Melakukan monitoring dan melakukan komunikasi yang } \\
\text { baik dengan pihak shipping line. }\end{array}$ \\
\hline 7 & $\begin{array}{l}\text { Mengirim draft PIB/PEB kepada pelanggan sebelum } \\
\text { dikirim ke Bea dan Cukai. }\end{array}$ \\
\hline 8 & $\begin{array}{c}\text { Saling berbagi informasi terkini mengenai ekspor impor, } \\
\text { lalu lintas dan lainnya. }\end{array}$ \\
\hline 9 & Pengecekan ulang dokumen dari pelanggan. \\
\hline 10 & $\begin{array}{l}\text { Melakukan komunikasi dengan pihak supplier pengirim } \\
\text { barang untuk menyelesaikan masalah. }\end{array}$ \\
\hline 11 & $\begin{array}{c}\text { Melakukan pemeliharaan pada alat komunikasi, gedung, } \\
\text { dan aset perusahaan lainnya. }\end{array}$ \\
\hline 12 & $\begin{array}{c}\text { Memilih bekerjasama dengan vendor trucking yang } \\
\text { profesional. }\end{array}$ \\
\hline 13 & Melakukan monitoring pada vendor warehouse. \\
\hline 14 & Menambah jumlah vendor trucking. \\
\hline 15 & $\begin{array}{c}\text { Memilih bekerjasama dengan vendor crane yang } \\
\text { profesional. }\end{array}$ \\
\hline 16 & Melakukan pemesanan trucking jauh sebelum hari $\mathrm{H}$. \\
\hline 17 & $\begin{array}{c}\text { Memilih bekerjasama dengan penyewaan warehouse yang } \\
\text { profesional. }\end{array}$ \\
\hline 18 & $\begin{array}{c}\text { Membuat rute alternatif yang menghindari lokasi } \\
\text { kepadatan. }\end{array}$ \\
\hline 19 & Update informasi terkini mengenai peramalan cuaca. \\
\hline 20 & Memprediksi banyaknya kapal curah yang akan berlayar. \\
\hline
\end{tabular}

\section{KESIMPULAN}

Hasil dari penelitian telah diidentifikasi 16 kebutuhan pelanggan dan didapatkan 3 prioritas kebutuhan pelanggan yaitu pengiriman yang mudah dan tepat waktu, pelayanan yang cepat dan pengiriman yang aman. Telah teridentifikasi 17 risiko dan didapatkan 3 prioritas risiko yaitu kerusakan alat komunikasi, kesalahan dalam pelayanan, dan kesalahan dalam penanganan dokumen. Telah teridiidentifikasi 24 penyebab risiko dan didapatkan 3 prioritas penyebab risiko yaitu kurangnya keterampilan karyawan, gangguan pada server INSW, dan kurangnya motivasi karyawan. Telah teridentifikasi 20 prioritas resilience measures dan didapatkan 3 prioritas yaitu memberikan pelatihan mengenai cara berkomunikasi yang baik, menggunakan sistem penilaian kinerja karyawan dengan KPI setiap bulan, dan memberikan pelatihan mengenai ekspor dan impor kepada karyawan.

\section{DAFTAR PUSTAKA}

[1] S. Dong-Wook and M. P. Panadiyes, Maritime Logistics, London, 2012.

[2] E. Conaway, "Guiding Principles for Building Strong Shipper-Carrier Relationship," Canadian Transportation Logistics, 2011.

[3] M. U. Albab, "Pengukuran dan Manajemen Risiko di Pelabuhan," Supply Chain Indonesia, 22 Juni 2016. [Online]. Available: https://supplychainindonesia.com/new/pengukuran-dan-manajemenrisiko-pada-pelabuhan/. [Accessed 2 Januari 2017].

[4] J. P. Vilko and J. M. Hallikas, "Int. J. Production Economics," Risk assessment in multimodal supply chains, vol. 140, no. 2, pp. 586-595, 2012.

[5] H. B. Carvalho, A. P. Machado, S. Azevedo and Cruz-Machado, "Computers \& Industrial Engineering," Supply chain redesign for resilience using simulation, vol. 62, no. 1, pp. 329-341, 2012.

[6] C. Zhu and G. Ji, Study on supply chain disruption risk management strategies and model, 2008.

[7] S. G. Azevedo, V. H. Machado, A. P. Barroso and V. C. Machado, Supply chain vulnerability: environment changes and dependencies., vol. 2, no. 1, pp. 51-55, 2008.

[8] J. S. Lam and X. Bai, A quality function deployment approach to improve maritime supply chain resilience, vol. 92, no. 8, pp. 16-27, 2016. 